\title{
What determines soil organic carbon stocks in the grazing lands of north-eastern Australia?
}

\author{
D. E. Allen ${ }^{\mathrm{A}, \mathrm{F}}$, M. J. Pringle ${ }^{\mathrm{A}}$, S. Bray ${ }^{\mathrm{B}}$, T. J. Hall' ${ }^{\mathrm{C}}$, P. O. O' Reagain ${ }^{\mathrm{D}}$, D. Phelps ${ }^{\mathrm{E}}$, \\ D. H. Cobon ${ }^{\mathrm{C}}$, P. M. Bloesch ${ }^{\mathrm{A}}$, and R. C. Dalal ${ }^{\mathrm{A}}$ \\ A Landscape Sciences (ESP), Department of Science, Information Technology, Innovation and the Arts, \\ GPO Box 5078, Brisbane, Qld 4001, Australia. \\ ${ }^{B}$ Agri-Science Queensland, Department of Agriculture, Fisheries and Forestry, PO Box 6014, \\ Rockhampton, Qld 4701, Australia. \\ ${ }^{\mathrm{C}}$ Science Engagement, Department of Science, Information Technology, Innovation and the Arts, \\ PO Box 102, Toowoomba, Qld 4350, Australia. \\ ${ }^{D}$ Agri-Science Queensland, Department of Agriculture, Fisheries and Forestry, PO Box 976, \\ Charters Towers, Qld 4820, Australia. \\ ${ }^{E}$ Agri-Science Queensland, Department of Agriculture, Fisheries and Forestry, PO Box 519, \\ Longreach, Qld 4730, Australia. \\ FCorresponding author. Email: Diane.Allen@science.dsitia.qld.gov.au
}

\begin{abstract}
This study aimed to unravel the effects of climate, topography, soil, and grazing management on soil organic carbon (SOC) stocks in the grazing lands of north-eastern Australia. We sampled for SOC stocks at 98 sites from 18 grazing properties across Queensland, Australia. These samples covered four nominal grazing management classes (Continuous, Rotational, Cell, and Exclosure), eight broad soil types, and a strong tropical to subtropical climatic gradient. Temperature and vapour-pressure deficit explained $>80 \%$ of the variability of SOC stocks at cumulative equivalent mineral masses nominally representing $0-0.1$ and $0-0.3 \mathrm{~m}$ depths. Once detrended of climatic effects, SOC stocks were strongly influenced by total standing dry matter, soil type, and the dominant grass species. At $0-0.3 \mathrm{~m}$ depth only, there was a weak negative association between stocking rate and climate-detrended SOC stocks, and Cell grazing was associated with smaller SOC stocks than Continuous grazing and Exclosure. In future, collection of quantitative information on stocking intensity, frequency, and duration may help to improve understanding of the effect of grazing management on SOC stocks. Further exploration of the links between grazing management and above- and below-ground biomass, perhaps inferred through remote sensing and/or simulation modelling, may assist large-area mapping of SOC stocks in northern Australia.
\end{abstract}

Received 31 January 2013, accepted 9 May 2013, published online 20 December 2013

\section{Introduction}

Rangelands occupy $>80 \%$ of Australia's land area and encompass a broad range of climate, land use, and geographical conditions (National Land and Water Resources Audit 2007, cited by Bastin and ACRIS Management Committee 2008). Recent reviews by Cook et al. (2010) and Dean et al. (2012a, 2012b) highlight Australia's unique rangeland conditions, including: $(i)$ pastoral production dominated by leasehold corporate pastoralists, with $>55 \%$ of Australian rangelands estimated to be managed as commercial livestock properties; (ii) a widespread occurrence of savanna fires across northern Australia; (iii) a predominance of shrubland and woodland, with a minority of scrub, heath, and herbland; and (iv) large variation in property sizes, from $<100$ to $>1000000$ ha.

Quantification of soil organic carbon (SOC) stocks in grazing landscapes is important for their management, since depletion of SOC stocks is one of the major threats to landscape sustainability, particularly where inputs such as fertiliser are not economically feasible. Further, with new opportunities through 'carbon offsets' and carbon-trading initiatives, there is increasing interest in the quantification of SOC stocks in Australian rangelands, and how SOC stocks relate to grazing management.

In a global review of grasslands, Piñeiro et al. (2010) found that SOC stocks: 'increased, decreased, or remained unchanged under contrasting grazing conditions across temperature and precipitation gradients suggesting that SOC accumulation is influenced by grazing management in a complex way'. In Australia, climate, soil and vegetation characteristics, fire, and grazing management have been identified as affecting northern rangeland carbon stocks (for examples, see Cook et al. 2010; Witt et al. 2011; Pringle et al. 2011; Dean et al. 2012a). Quantification of the spatial variability of SOC stocks and factors associated with SOC cycling is needed to assist 
simulation modelling of the impacts of grazing management (Liu et al. 2011; Dean et al. 2012b), since measured data for longer term (decadal and older) experimental sites in Australian rangelands are limited.

The aim of this study was to investigate the effects of climate, topography, soil, and grazing management on the variability of SOC stocks in the rangelands of Queensland, Australia. This extensive land use occupies $\sim 80 \%$ ( $138 \mathrm{Mha})$ of Queensland's land area and comprises $\sim 28.4 \%$ of the total area of rangelands in Australia (Australian Government Department of Sustainability, Environment, Water, Population and Communities 2013). In particular, we considered the two questions: what is the range of SOC stock values at depth intervals of $0-0.1$ and $0-0.3 \mathrm{~m}$ in the soil profile; and across a regional climatic gradient, what aspects of grazing management (if any) are associated with SOC stocks?

\section{Materials and methods}

\section{Site information}

Sites from a range of soil types and climatic regions throughout Queensland, Australia, were considered for this study. The sites also represented a range of grazing-management strategies, defined as (Department of Environment and Resource Management 2011):

- Continuous (or set) stocking. Pastures are grazed most of the year and rarely, if ever, do the pastures receive a spell from grazing. Hall et al. (2011) describes 'continuous' strategy as being grazed for 9-11 months of the year.

- Rotational grazing. A period of grazing is followed by a period of rest for the pasture. Depending on pasture growth, these grazing and rest periods may vary from days to months.

- Cell (or time-controlled) grazing. A form of intensive rotational grazing where many relatively small paddocks enable a short grazing period at heavy stocking rates, followed by a long recovery period.

In addition to the strategies described above, 'Exclosure' was defined as an absence of grazing. Ninety-eight sites across 18 properties were considered suitable for the study (Fig. 1) based on detailed grazing management history (10 years or the best available) information including stocking rate, animal size/ weight, grazing duration in paddock, pasture composition, fire and fertiliser history, as well as available soil and property

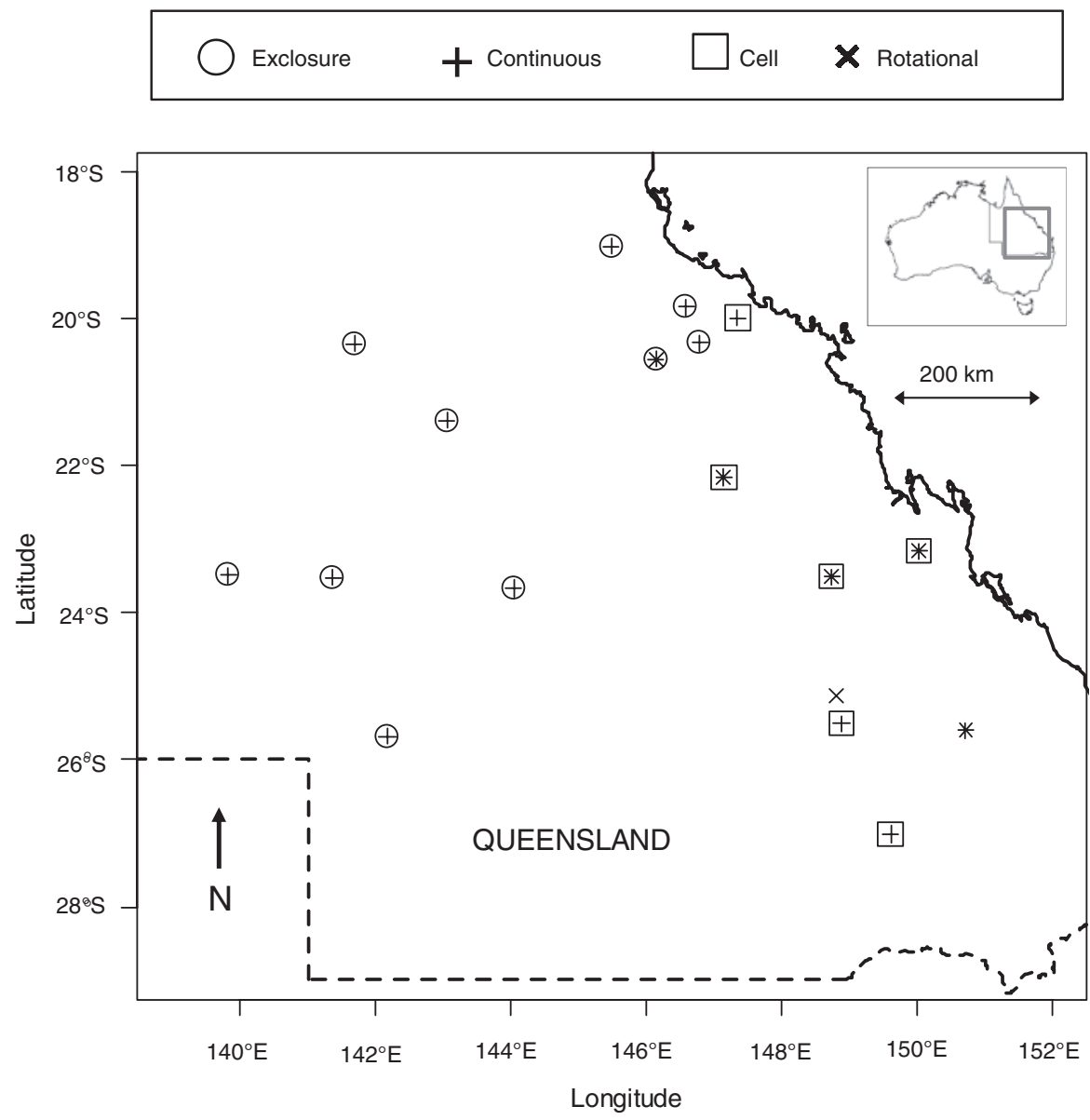

Fig. 1. Locations of the 18 grazing properties sampled in Queensland, Australia. The state boundary of Queensland is shown as a dashed line. The classes of grazing management present at each property are indicated according to the legend. 
information (at the scale of the soil and paddock maps) and site accessibility.

\section{Soil collection}

The sampling approach for this study was broadly based on the recommendation of Pringle et al. (2011). Ten samples were taken from an area of interest (termed 'site' herein), which varied in size according to the prevailing soil type, described to Order-level in the Australian Soil Classification (Isbell 2002) according to best available soil information, and management unit (e.g. paddock). Samples were spread throughout the site in a grid design with a random point of origin (de Gruijter et al. 2006). Using a drill-rig fitted with a 0.043-m-diameter pushtube, a core of soil was taken to at least $0.3 \mathrm{~m}$ depth, but to $0.5 \mathrm{~m}$ where possible, and sectioned at depths of $0-0.1,0.1-0.2$, $0.2-0.3$, and (where possible) $0.3-0.5 \mathrm{~m}$. Individual samples were sealed in plastic bags and transported for processing.

\section{Compositing procedure for carbon analysis}

The 10 soil profiles $(0-0.1,0.1-0.2,0.2-0.3 \mathrm{~m})$ at a site were reexamined for similarity of soil type, with the aim of excluding any obvious outliers before compositing. Identification of outliers within the soil profiles was determined by a combination of field-based identification, and principal component analysis (PCA) of the combined mid-infrared spectra of the $0-0.1$ and $0.3-0.5 \mathrm{~m}$ depth intervals.

Infrared spectra of the soil samples were measured using diffuse reflectance infrared Fourier transform spectroscopy (DRIFTS). Soil samples were air-dried to $40^{\circ} \mathrm{C}$ and sieved to $<2 \mathrm{~mm}$, then a subsample of the $<2-\mathrm{mm}$ soil was ground to $0.5 \mathrm{~mm}$ before infrared analysis. A PerkinElmer Spectrum One Fourier transform mid-infrared (FT-IR) spectrometer (PerkinElmer, Wellesley, MA) equipped with a PIKE Technologies Automated Diffuse Reflectance Accessory (PIKE Technologies, Madison, WI) was used to measure the infrared spectra. Scans were taken at $2 \mathrm{~cm}^{-1}$ intervals in the wavenumber range $7800-450 \mathrm{~cm}^{-1}(1.28-22 \mu \mathrm{m})$. The final spectrum for each sample was an average of 60 scans. Spectra were expressed in absorbance units $[\log (1 /$ reflectance)]. Background reference scans (average of 240 scans) were performed on a silicon carbide disc, assumed to have a reflectivity of $1(100 \%)$.

The mid-infrared region $\left(4000-450 \mathrm{~cm}^{-1}\right)$ was used for the PCA. The baseline of each spectrum was removed by subtracting a convex hull fitted to the spectrum, and the spectra of the $0-0.1$ and $0.3-0.5 \mathrm{~m}$ depths for each profile were combined to increase the soil-type discrimination (Viscarra Rossel and Webster 2011). The PCA (meancentred) was carried out on the combined spectra, and those components that described $99 \%$ of the data were retained. A two-dimensional representation of the multidimensional space was obtained using Sammon mapping, which is the best twodimensional representation of distances between objects that occur in multidimensional space (Sammon 1969). Soil profiles that were obvious outliers were detected visually in the Sammon map, with any obvious outliers identified through this process discarded from the compositing process. Remaining profiles were composited on their depth intervals $(0-0.1, \quad 0.1-0.2, \quad 0.2-0.3 \mathrm{~m})$, in proportion to their bulk densities, to produce a single composite profile (0-0.1, $0.1-0.2,0.2-0.3 \mathrm{~m}$ ) for carbon analysis.

\section{Determination of carbon concentration}

Composite samples to $0.3 \mathrm{~m}$ depth were transported to CSIRO Land and Water - Waite Campus, Glen Osmond, South Australia, for measurement of SOC concentration by dry combustion (see Baldock et al. 2013, this issue). Briefly, a 10 -mg subsample was selected from each of the composite samples and finely ground using a using a Retsch MM400 Mixer Mill (RETSCH GmbH, Haan, Germany). Prior to organic carbon analysis, all samples were tested for the presence of inorganic carbon using $1 \mathrm{M} \mathrm{HCl}$ and a visual assessment for effervescence, whereby: (i) samples showing positive response (effervescence) were pre-treated with $\mathrm{H}_{2} \mathrm{SO}_{3}$ ( $1 \mathrm{~mL} \mathrm{H}_{2} \mathrm{SO}_{3}$ applied to $0.8 \mathrm{~g}$ soil placed in nickel-lined ceramic LECO boats set on a hot-plate at $100^{\circ} \mathrm{C}$ ) then analysed by high temperature combustion (LECO C-144); or (ii) samples showing a negative response (no effervescence) were analysed by high temperature combustion (LECO CNS2000) (LECO Corporation, St. Joseph, MI).

\section{Determination of bulk density}

Bulk density was determined on a subsample of the individual samples by dividing the oven-dry soil weight of the sample (dried for 3 days at $105^{\circ} \mathrm{C}$; Linn and Doran 1984) by the volume of the soil core for the depth interval of interest. Since a composite soil sample was used to measure carbon concentration, we averaged (i) bulk density at each depth interval within a site, and (ii) the mass fraction of gravel $(\geq 2 \mathrm{~mm})$ observed. These averages are herein denoted $\rho_{\mathrm{b} \text {,obs }}$ and $p_{\mathrm{g}}$, respectively. Quantification of $\rho_{\mathrm{b}, \mathrm{obs}}$ was complicated by the fact that, for sites where the Vertosol Soil Order (Isbell 2002) occurs, the soil expands and contracts depending on its moisture content. To account for this we standardised $\rho_{\mathrm{b}, \mathrm{obs}}$ for Vertosol to the bulk density at field capacity (denoted herein as $\rho_{\mathrm{b}, \mathrm{FC}}$ ) by minimising a model of three-dimensional swelling (Yule 1984):

$$
\left|\rho_{\mathrm{b}, \mathrm{obs}}-\rho_{\mathrm{b}, \mathrm{FC}}\left\{1-\rho_{\mathrm{b}, \mathrm{FC}}\left(\theta_{\mathrm{g}, \mathrm{FC}}-\theta_{\mathrm{g}, \mathrm{obs}}\right)^{-1 / 3}\right\}\right|=0
$$

where $\theta_{\mathrm{g}, \mathrm{FC}}$ was the gravimetric moisture content of the soil at field capacity, and $\theta_{\mathrm{g}, \mathrm{obs}}$ was the gravimetric moisture content at the time of sampling, determined at $105^{\circ} \mathrm{C}$ according to Linn and Doran (1984). We assumed $\theta_{\mathrm{g}, \mathrm{FC}}=0.36 \mathrm{~g} \mathrm{~g}^{-1}$, which in our experience is a reasonable value for grey Vertosol soil that predominately occurs in the rangelands of north-eastern Australia. Results of the minimisation were constrained to the interval $1<\rho_{\mathrm{b}, \mathrm{FC}}<1.7 \mathrm{Mg} \mathrm{m}^{-3}$. For Soil Orders other than Vertosol $\rho_{\mathrm{b}, \mathrm{FC}}=\rho_{\mathrm{b}, \mathrm{obs}}$.

\section{Calculation of SOC stocks}

SOC stock (denoted herein as $C_{\mathrm{s}}$, units of $\mathrm{Mgha}^{-1}$ ) was computed as:

$$
C_{\mathrm{s}}=\sum_{i=1}^{n}\left(\Delta \times \frac{\hat{C}_{i}}{1000} \times \hat{\rho}_{\mathrm{b}, \mathrm{FC}, i} \times\left\{1-\hat{p}_{\mathrm{g}, i}\right\} \times 10000\right)
$$

where, for the $i$ th of $n$ discrete layers in the profile, $\Delta$ was thickness of the layer $(\mathrm{m}) ; \hat{C}_{i}$ was an estimate of SOC 
concentration measured directly by dry combustion $\left(\mathrm{mg} \mathrm{g}^{-1}\right)$ for the layer; $\hat{\rho}_{\mathrm{b}, \mathrm{FC}, 1 i}$ was an estimate of bulk density at field capacity $\left(\rho_{\mathrm{b}, \mathrm{FC}}\right) ; \hat{p}_{\mathrm{g}, i}$ was an estimate of $p_{\mathrm{g}}$ (unitless); and 10000 was a conversion factor. See below for how $n$ was defined. Note that Eqn 2 differs from the method of Pringle et al. (2011), who accounted explicitly for the carbon concentrations of the gravel fraction and Fe-Mn concretions in their estimates of $C_{\mathrm{s}}$; in practice, we have found that the difference between the two methods is negligible (M. J. Pringle, unpubl. data). The estimates $\hat{C}_{i}, \hat{\rho}_{\mathrm{b}, \mathrm{FC}, i}$, and $\hat{p}_{\mathrm{g}, i}$ were obtained by disaggregating the respective depth functions of $\hat{C}, p_{\mathrm{b}, \mathrm{FC}}$, and $p_{\mathrm{g}}$ at $\Delta=0.01-\mathrm{m}$ increments in each profile to the maximum sampling depth, using the mass-preserving spline (Bishop et al. 1999; Malone et al. 2009) with smoothness parameter held constant at 0.01 .

To define $n$ in Eqn 2 we followed the method of Pringle et al. (2011). First, the spline predictions $\hat{\rho}_{\mathrm{b}, \mathrm{FC}}$, were used to find the location with the smallest cumulative soil mass, $M_{\mathrm{d}, \min }$, at depths $d=(0.1 \mathrm{~m}, 0.3 \mathrm{~m})$. Then $n$ for each sampled location was taken as the number of $0.01-\mathrm{m}$ increments between the soil surface and the depth where $M_{\mathrm{d} \text {,min }}$ was reached. The effect of this procedure was that $C_{\mathrm{s}}$ related to the mass-based ('material') - rather than depth-based ('geographic')coordinate system that is favoured for soil carbon inventory (Gifford and Roderick 2003; McBratney and Minasny 2010), nominally representing $0-0.1$ and $0-0.3 \mathrm{~m}$ depth.

\section{Explanatory variables}

Based on site-selection criteria, there were 25 explanatory variables to consider (Table 1). Climatic data (Jeffrey et al. 2001) and topographic attributes (Speight 2008) were provided by CSIRO Land and Water - Waite Campus, Glen Osmond, South Australia. Clay and silt content of the composite samples was measured by the hydrometer method (Rayment and Higginson 1992); $\mathrm{pH}$ and electrical conductivity (1:5 water) of the composite samples were measured according to Rayment and Higginson (1992). Measured nitrogen data, an obvious explanatory variable, were unavailable for inclusion in this analysis due to the analytical instrumentation used to analyse SOC in this study (see Baldock et al. 2013, this issue). Grazing management information-grazing management class, total standing dry matter (TSDM), stocking rate-was obtained (directly, where possible, or similarly classified) from Hall et al. (2011). The TSDM at Exclosure sites was estimated using GRASP model data (Rickert et al. 2000) and reflects production potential rather than actual growth as a result of grazing activity. Variables were allocated to one of four groups (Climate, Topography, Soil, or Grazing Management; Table 1). Inside each group, variables were ranked by their preference of use. Rank was influenced by our perception of how the variables might influence SOC stocks, their certainty, and spatial density. Note that the three climate-related variables in Table 1 are 5-year averages. Longer term climatic information

Table 1. Pool of explanatory variables used to examine the variability of SOC stock

Variables were ranked within a group according to the preference of use, decided subjectively by the authors. Values taken by each variable are classified as either categorical (Categ.) or continuous (Cont.). AE, Animal equivalent, which, in northern rangelands, is generally defined as intake relative to a 450-kg steer at liveweight maintenance; classes of dom Grass: Native Perennial, Exotic Buffel, or Exotic Other; classes of distWat: $<1,1-2$, or 2-3 km; classes of anSupp: (i) no supplement, (ii) application of urea in dry season (or any time in drought), (iii) phosphorus in wet season (any year), or (iv) both urea and phosphorus applied

\begin{tabular}{|c|c|c|c|c|c|}
\hline Group & Rank & Name & Description & Unit & Value \\
\hline \multirow[t]{5}{*}{ Soil } & 1 & soilOrder & Order of the Australian Soil Classification (Table 2) & - & Categ. \\
\hline & 2 & clay & Clay content $\mathrm{A}^{\mathrm{A}}$ & $\%$ & Cont. \\
\hline & 3 & $p H$ & $\mathrm{pH}(1: 5 \text { water })^{\mathrm{A}}$ & - & Cont. \\
\hline & 4 & silt & Silt content ${ }^{\mathrm{A}}$ & $\%$ & Cont. \\
\hline & 5 & $E C$ & Electrical conductivity $(1: 5 \text { water })^{\mathrm{A}}$ & $\mathrm{dS} \mathrm{m}^{-1}$ & Cont. \\
\hline \multirow[t]{9}{*}{ Grazing management } & 1 & grazMan & Class of grazing management (Table 2) & - & Categ. \\
\hline & 2 & sRate & Average stocking rate, $2001-10$ & ha per $\mathrm{AE}$ & Cont. \\
\hline & 3 & sumTSDM & Sum of total standing dry matter, 2005-09 & $\mathrm{kgha}^{-1}$ & Cont. \\
\hline & 4 & meanTSDM & Mean of total standing dry matter, 2005-09 & $\mathrm{kg} \mathrm{ha}^{-1}$ & Cont. \\
\hline & 5 & $\operatorname{sigTSDM}$ & Variance of total standing dry matter, 2005-09 & $\left(\mathrm{kg} \mathrm{ha}^{-1}\right)^{2}$ & Cont. \\
\hline & 6 & nFire & Number of fires since 2001 & Count & Cont. \\
\hline & 7 & domGrass & Class of dominant perennial grass & - & Categ. \\
\hline & 8 & distWat & Class of average distance to water & - & Categ. \\
\hline & 9 & anSupp & Class of animal supplement used & - & Categ. \\
\hline \multirow[t]{3}{*}{ Climate $^{\mathrm{B}}$} & 1 & rain5 & Mean annual rainfall, 2006-10 & $\mathrm{mm}$ & Cont. \\
\hline & 2 & temp5 & Mean annual daily temperature, 2006-10 & ${ }^{\circ} \mathrm{C}$ & Cont. \\
\hline & 3 & VPD5 & Mean annual vapour pressure deficit, 2006-10 & $\mathrm{kPa}$ & Cont. \\
\hline \multirow[t]{8}{*}{ Topography } & 1 & slope & Inclination of the land surface from the horizontal & $\%$ & Cont. \\
\hline & 2 & FM300slope & Median slope within a $300-\mathrm{m}$ radius & $\%$ & Cont. \\
\hline & 3 & $T W I$ & Topographic wetness index & - & Cont. \\
\hline & 4 & FR300elev & Range of elevation within a $300-\mathrm{m}$ radius & $\mathrm{m}$ & Cont. \\
\hline & 5 & planCurv & Plan curvature & - & Cont. \\
\hline & 6 & profCurv & Profile curvature & - & Cont. \\
\hline & 7 & asp & Direction the slope faces & Degrees & Cont. \\
\hline & 8 & slopeRel & Class of slope-relief & - & Categ. \\
\hline
\end{tabular}

${ }^{\mathrm{A}}$ Rayment and Higginson (1992). ${ }^{\mathrm{B}}$ Jeffrey et al. (2001). ${ }^{\mathrm{C}}$ Speight (2008). 
was available, in the form of 30-year averages, but this information was not used because preliminary analysis revealed that the length of the time-period had negligible effect on the modelling outcomes that are described below.

Within each of the four groups of explanatory variables in Table 1, redundant information was identified. For pairs of variables within a group, we computed either $(i)$ the rank correlation coefficient $\left(r_{\mathrm{s}}\right)$ for pairs of continuous explanatory variables; or (ii) Cohen's index-of-agreement ( $\kappa)$ (Cohen 1960), a statistic analogous to a correlation coefficient to assess interrater agreement for pairs of categorical variables. A rank correlation of $r_{\mathrm{s}}>0.9$ and an index of agreement of $\kappa>0.8$ were subjectively identified as 'very strong' and used for inclusion in analysis.

\section{Statistical modelling}

Unless otherwise stated, all analysis described herein was done with aid of the R statistical software (R Core Team 2013). We transformed SOC stocks to natural logarithms to stabilise variance. The transformed data are denoted $\log \left(C_{\mathrm{s}}\right)$.

A random forest (Breiman 2001) was used to efficiently identify the subset of non-redundant explanatory variables that had the greatest effect on the variability of SOC stocks. The response variable of the random forest was $\log \left(C_{\mathrm{s}}\right)$ at either $0-0.1$ or $0-0.3 \mathrm{~m}$. A random forest is similar to a regression tree, except that many trees are grown, and an ensemble prediction of the response variable is obtained. Features of the random forest that make it attractive for this study include: (i) it deals implicitly with non-linearity and interactions, (ii) it caters for both continuous and categorical explanatory variables, and (iii) it can quickly estimate the relative importance of each explanatory variable to the response variable. The last is done by shuffling the values of each explanatory variable in turn, which induces noise in the dataset. Those explanatory variables with the greatest importance to the model are those that, upon shuffling, decrease most the accuracy of the model, which is tracked with an internal measure of mean squared error (MSE) (Breiman 2001). Importances fluctuate slightly between runs of the random forest, so a robust ranking was obtained by running the algorithm 100 times for each nominal depth interval.

The random-forest importances suggested that climate was the dominant influence on variability in $\log \left(C_{\mathrm{s}}\right)$. With this in mind we fitted the following generalised additive model (GAM) (Hastie and Tibshirani 1990) to SOC stocks at both depth intervals:

$$
\log \left(C_{\mathrm{s}}\right)=f(\text { temp } 5, \text { VPD5 })+\varepsilon_{\mathrm{GAM}}
$$

where the explanatory variables are named as in Table $1, f(\cdot)$ denotes a cubic regression spline applied to the pair of climaterelated explanatory variables, and $\varepsilon_{\mathrm{GAM}}$ is the model residual. A cubic regression spline is a set of cubic polynomials, joined end-to-end to form a 'wiggly' function (an accepted term in the spline-fitting literature). Detailed mathematics behind the fitting of a GAM is given in Hastie and Tibshirani (1990) and Wood (2008). The fitting procedure uses a generalised cross-validation statistic to optimise the balance between function wiggliness and goodness-of-fit. In the interest of parsimony, wiggliness must be minimised. By incorporating the pair of climate-related explanatory variables into a single spline, the interaction - which we expected to be strong-was implicitly considered.

The next step was to examine whether $\varepsilon_{\mathrm{GAM}}$, which represented $\log \left(C_{\mathrm{s}}\right)$ detrended of climatic effects, could be related to grazing management and the other explanatory variables identified as important by the random forest. With the aid of in-house software, the following linear mixed model (LMM) (Pringle et al. 2011) was fitted:

$$
\begin{aligned}
\varepsilon_{\mathrm{GAM}}= & \text { sumTSDM }+ \text { sigTSDM }+ \text { FM300slope } \\
& + \text { sRate }+ \text { soilOrder }+ \text { domGrass } \\
& + \text { grazMan }+\varepsilon_{\mathrm{LMM}}
\end{aligned}
$$

where the first seven terms on the right-hand side represent the 'fixed' effects of the model, and $\varepsilon_{\mathrm{LMM}}$ represents the random effects. The latter was assumed to be a realisation of a zeromean, second-order stationary random function, parameterised by an exponential variogram (Webster and Oliver 2001). The LMM was fitted by maximising the residual log-likelihood function $\left(l_{R}\right)$, by simulated annealing (Lark and Cullis 2004). Welham and Thompson (1997) proposed a statistic, $D$, to test a null hypothesis that particular fixed effects in the LMM are zero:

$$
D=-2\left(l_{R, \text { full }}-l_{R, \text { nested }}\right)
$$

where $l_{R \text {,full }}$ is the residual $\log$-likelihood of Eqn 4 , and $l_{R \text {,nested }}$ is the residual log-likelihood of Eqn 4 when one or more of the fixed effects has been set to zero. Equation 5 is a likelihood ratio for the null hypothesis on the fixed effects, which is approximated by a chi-square distribution, with degrees-offreedom equivalent to the number of fixed effects that were set to zero. Note that our intention with the LMM was to explain the main effects of the explanatory variables only, not their interactions, with particular emphasis on the role of variable grazMan (grazing management).

\section{Results}

\section{Soil organic carbon stocks}

A large proportion of the soils sampled had $\mathrm{pH}>7.0$ (Table 2) and showed a positive response to $1 \mathrm{M} \mathrm{HCl}$ effervescence test; therefore, most samples required $\mathrm{H}_{2} \mathrm{SO}_{3}$ pre-treatment for determination of $\%$ organic carbon by combustion. The range of values for observed $C_{\mathrm{s}}$ across all grazing types at a (nominal) depth of $0-0.3 \mathrm{~m}$ was 4.8-83.7 $\mathrm{Mg} \mathrm{ha}^{-1}$, with a mean of $28.7 \mathrm{Mg} \mathrm{ha}^{-1}$ (Table 2). At a (nominal) depth of $0-0.1 \mathrm{~m}$ the range was $1.6-33.8 \mathrm{Mg} \mathrm{ha}^{-1}$, with a mean of $11.6 \mathrm{Mg} \mathrm{ha}^{-1}$ (data not shown). Note that the $C_{\mathrm{s}}$ values reported in Table 2 represent raw means and ranges of the observed data; formal statistical analysis was required to deal with the apparent positive skew and confounding by a strong climatic gradient. We dealt with these effects by: $(i)$ transforming data to natural logarithms to minimise skew (Fig. 2); and, (ii) using a GAM (reported below) to detrend for climatic effects. 
Table 2. Site information and soil parameters (average with range in parentheses) at $\mathbf{0}-\mathbf{0 . 3} \mathrm{m}$ soil depth for the grazing management sites Ch, Chromosol; De, Dermosol; Hy, Hydrosol; Ka, Kandosol; Ru, Rudosol; So, Sodosol; Te, Tenosol; Ve, Vertosol (Isbell (2002)

\begin{tabular}{|c|c|c|c|c|c|c|c|c|c|}
\hline $\begin{array}{l}\text { Grazing } \\
\text { management }\end{array}$ & $\begin{array}{l}\text { No. of } \\
\text { sites }\end{array}$ & Soil Order & $\begin{array}{c}\text { 5-year annual } \\
\text { temp. }\left({ }^{\circ} \mathrm{C}\right)\end{array}$ & $\begin{array}{l}\text { 5-year rainfall } \\
(\mathrm{mm})\end{array}$ & $\begin{array}{c}\text { Clay content } \\
(\%)^{\mathrm{A}}\end{array}$ & $\mathrm{pH}^{\mathrm{A}}$ & $\begin{array}{c}\text { Organic carbon } \\
(\%)^{\mathrm{B}}\end{array}$ & $\begin{array}{l}\text { Bulk density at } \\
\text { field capacity } \\
\qquad\left(\rho_{\mathrm{b}, \mathrm{FC}}\right)^{\mathrm{C}}\end{array}$ & $\begin{array}{l}\text { Carbon stock } \\
\left(\mathrm{Mgha}^{-1}\right)^{\mathrm{C}}\end{array}$ \\
\hline Continuous & 28 & $\mathrm{Ch}, \mathrm{De}, \mathrm{Ka}, \mathrm{So}, \mathrm{Te}, \mathrm{Ve}$ & $\begin{array}{c}23.2 \\
(20.1-25.7)\end{array}$ & $\begin{array}{c}700 \\
(256-1138)\end{array}$ & $\begin{array}{c}36 \\
(15-75)\end{array}$ & $\begin{array}{c}7.2 \\
(5.7-9.2)\end{array}$ & $\begin{array}{c}0.56 \\
(0.13-2.96)\end{array}$ & $\begin{array}{c}1.32 \\
(1.00-1.73)\end{array}$ & $\begin{array}{c}17.86 \\
(4.79-75.49)\end{array}$ \\
\hline Rotational & 28 & $\mathrm{Ch}, \mathrm{De}, \mathrm{Ka}, \mathrm{So}, \mathrm{Ve}$ & $\begin{array}{c}22.6 \\
(20.5-23.8)\end{array}$ & $\begin{array}{c}760 \\
(630-844)\end{array}$ & $\begin{array}{c}35 \\
(12-64)\end{array}$ & $\begin{array}{c}7.0 \\
(5.2-9.2)\end{array}$ & $\begin{array}{c}0.84 \\
(0.14-2.43)\end{array}$ & $\begin{array}{c}1.46 \\
(1.18-1.69)\end{array}$ & $\begin{array}{c}29.04 \\
(9.07-54.09)\end{array}$ \\
\hline Cell & 32 & $\mathrm{Ch}, \mathrm{De}, \mathrm{Hy}, \mathrm{Ru}, \mathrm{Ve}$ & $\begin{array}{c}22.1 \\
(20.5-23.8)\end{array}$ & $\begin{array}{c}755 \\
(568-1138)\end{array}$ & $\begin{array}{c}34 \\
(9-57)\end{array}$ & $\begin{array}{c}6.9 \\
(5.2-9.1)\end{array}$ & $\begin{array}{c}1.02 \\
(0.21-3.43)\end{array}$ & $\begin{array}{c}1.42 \\
(1.08-1.66)\end{array}$ & $\begin{array}{c}34.72 \\
(13.60-83.71)\end{array}$ \\
\hline Exclosure & 10 & Ch, De, So, Ve & $\begin{array}{c}24.1 \\
(22.7-25.7)\end{array}$ & $\begin{array}{c}581 \\
(256-925)\end{array}$ & $\begin{array}{c}32 \\
(18-59)\end{array}$ & $\begin{array}{c}7.3 \\
(6.0-8.5)\end{array}$ & $\begin{array}{c}0.51 \\
(0.14-1.52)\end{array}$ & $\begin{array}{c}1.34 \\
(1.02-1.68)\end{array}$ & $\begin{array}{c}16.56 \\
(5.21-33.72)\end{array}$ \\
\hline
\end{tabular}

${ }^{\text {A }}$ Measured according to Rayment and Higginson (1992) for 0-30 cm soil depth.

${ }^{\mathrm{B}}$ Measured by dry combustion according to Baldock et al. (2013, this issue).

${ }^{\mathrm{C}}$ Determined on composite sample at each site (see Methods for calculations).

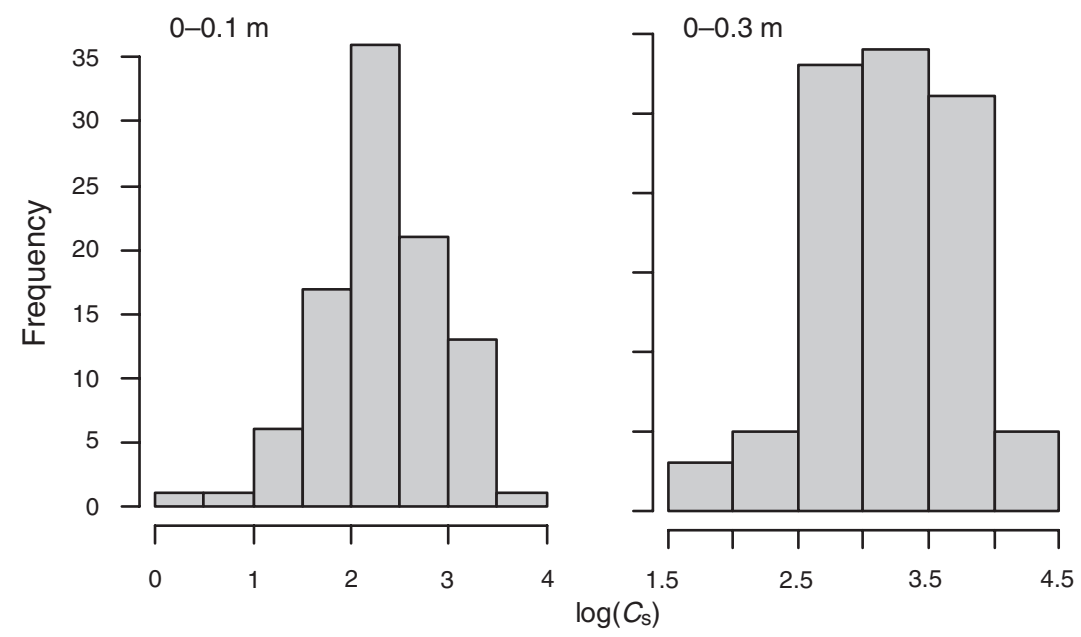

Fig. 2. Histograms of $\log$-transformed SOC stock $\left(\log \left(C_{\mathrm{s}}\right) ; C_{\mathrm{s}}\right.$ originally as $\left.\mathrm{Mg} \mathrm{ha}^{-1}\right)$. Note that the depth intervals are only nominal because SOC was computed on the basis of equivalent soil mineral mass.

Influence of the explanatory variables on soil organic carbon stocks

Following the search for redundancy in the explanatory variables, 23 variables were retained for further analysis. The two redundant variables were meanTSDM and FR300elev. According to the ranked importances returned by the random forest (Fig. 3), at both $0-0.1$ and $0-0.3 \mathrm{~m}$ we considered nine common variables to be influential on $\log \left(C_{\mathrm{s}}\right)$ (from Table 1): temp5, VPD5, sumTSDM, rain5, FM300slope, sigTSDM, sRate, soilOrder, and domGrass. That two of the first three explanatory variables were related to climate suggested the presence of a strong regional trend. The consistently least important variables related to topographic curvature. The categorical variable grazMan was at the lower end of importance, which reflects either: (i) the large amount of fuzziness in the definitions and practical application of 'Continuous', 'Rotational', and 'Cell' grazing management, including their interaction with stocking rate and impact on vegetation productivity and land condition; or (ii) that soil organic carbon responds strongly to climate and soil type irrespective of the grazing management system.

On the basis of the above importances, we initially tried to fit Eqn 3 as $f($ temp $5, V P D 5$, rain 5 ), but there were too few data to support such a complex model. We therefore sacrificed rain5, which, contrary to our ranking (Table 1), was actually the least important of the three climatic variables. Fitting diagnostics for Eqn 3 (not shown) revealed that $f(t e m p 5, V P D 5)$ was strongly significant $(P<0.001)$ at each depth interval. At $0-0.1 \mathrm{~m}$ depth, $84 \%$ of the variability of $\log \left(C_{\mathrm{s}}\right)$ was explained; at $0-0.3 \mathrm{~m}$ depth $87 \%$ was explained. The predicted surfaces of $\log \left(C_{\mathrm{s}}\right)$ for $f($ temp 5,VPD5) are shown in Fig. 4. Note that the climatic variables have relatively few unique values because their spatial resolution is $5 \mathrm{~km}$. For $0-0.1 \mathrm{~m}$ depth (Fig. $4 a$ ), the surface was strongly non-linear, with the largest values of $\log$ $\left(C_{\mathrm{S}}\right)$ occurring where temp5 and VPD5 were relatively small. This was expected because relatively cool and wet environments 


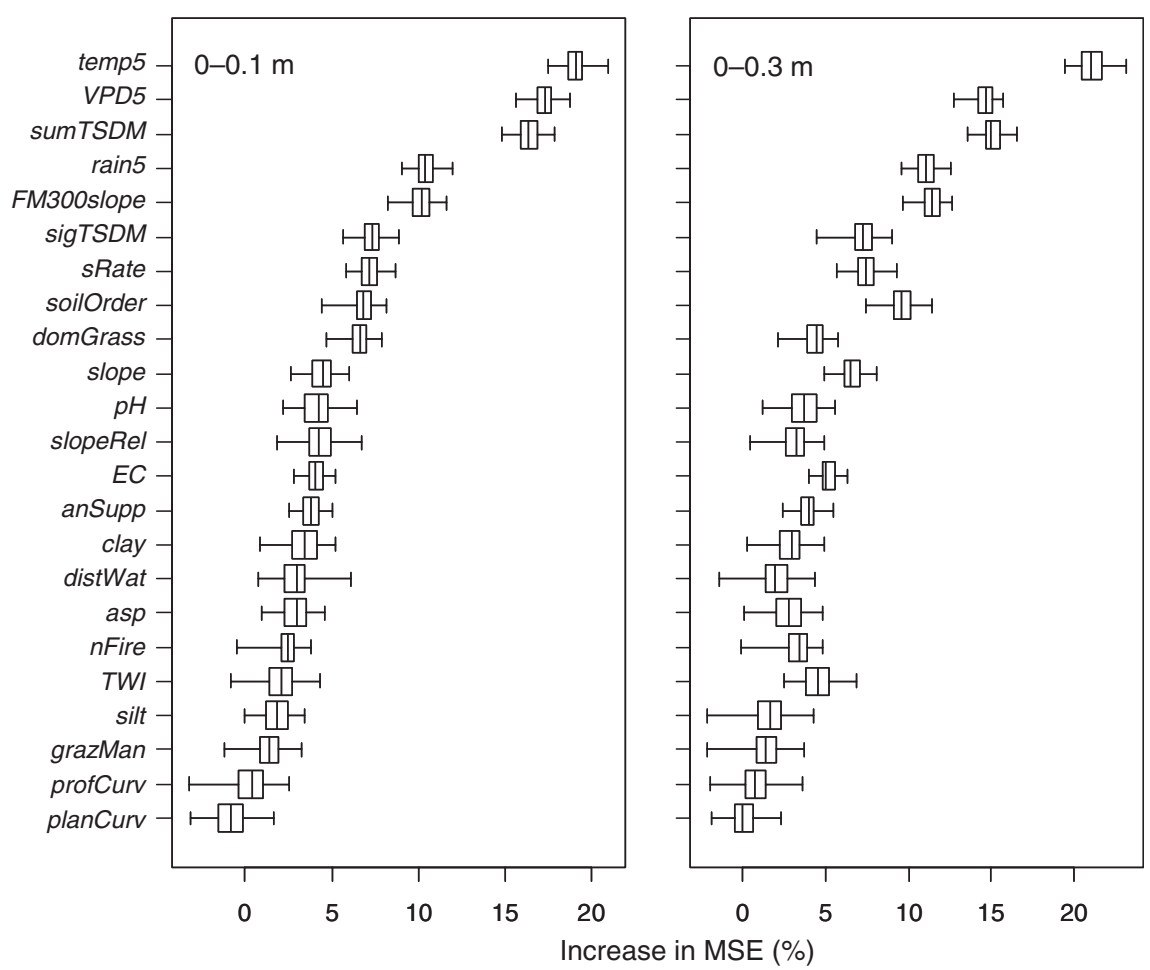

Fig. 3. Relative importance of the explanatory variables to the variation of SOC stocks at (nominal) depth intervals of $0-0.1$ and $0-0.3 \mathrm{~m}$. The whiskers of the box-and-whisker plots denote data extremes. MSE, Mean squared error. Importance decreases down the plot.
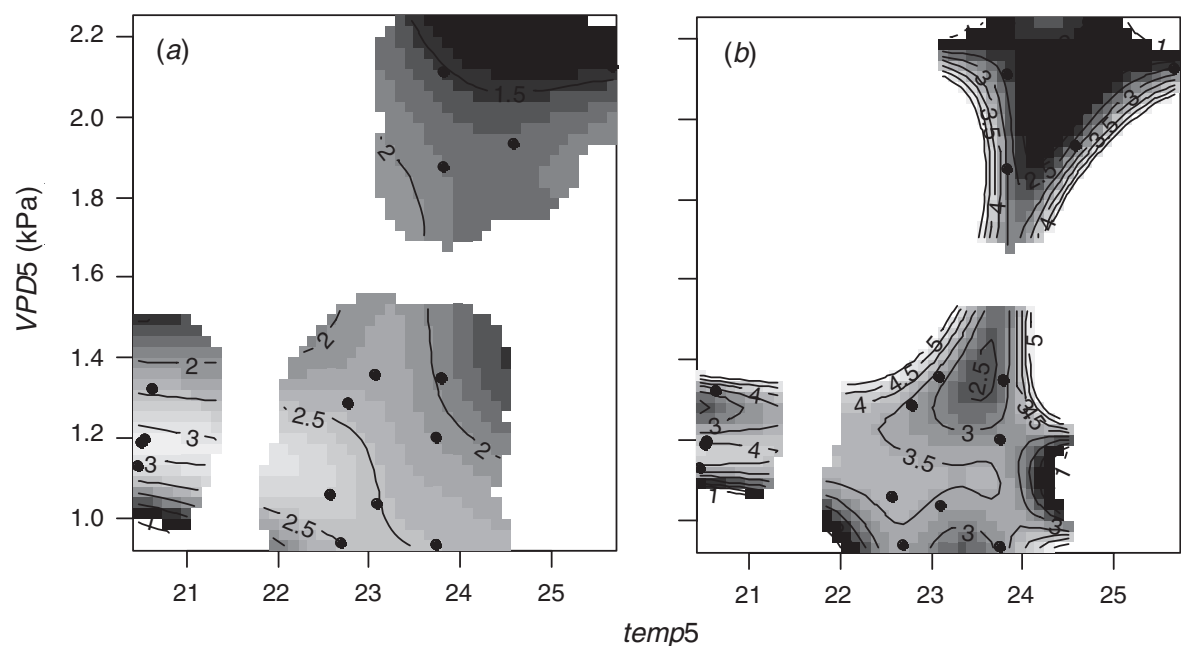

Fig. 4. From the generalised additive model in Eqn 3, these plots are the predictions of $f(t e m p 5, V P D 5)$ for $\log$-transformed SOC stock $\left(\log \left(C_{\mathrm{s}}\right) ; C_{\mathrm{s}}\right.$ originally as $\left.\mathrm{Mgha}^{-1}\right)$ at: $(a) 0-0.1 \mathrm{~m}$ (nominal) depth, and $(b)$ $0-0.3 \mathrm{~m}$ (nominal) depth. Observations are shown as black dots. White space indicates a part of the surface considered too far from an observation to be a reliable prediction.

tend to accumulate (or possibly lose more slowly) SOC compared with hot and dry environments (Wynn et al. 2006). For $0-0.3 \mathrm{~m}$ depth, the surface of $f($ temp $5, V P D 5)$ (Fig. $4 b$ ) was more variable than for the $0-0.1 \mathrm{~m}$ depth, but the pattern of the trend was similar.

Parameter values for the fixed effects of the LMM and the outcomes of the hypothesis testing are shown in Table 3. The latter revealed that sumTSDM, soilOrder, and domGrass strongly affected $\varepsilon_{\mathrm{GAM}}$ at both depth intervals. Table 3 shows that sumTSDM had a positive effect on $\varepsilon_{\mathrm{GAM}}$ at both depths, as expected. The reference classes for soilOrder and domGrass, which were implied in the model intercept, were 'Vertosol' and 'Native Perennial', respectively. Without resorting to further pairwise testing, it was clear that the class 'Hydrosol' was 
Table 3. Fixed effects of the linear mixed model (Eqn 4) for log-transformed SOC stocks $\left(\log \left(C_{\mathrm{s}}\right) ; C_{\mathrm{s}}\right.$ originally as $\mathrm{Mg} \mathrm{ha}^{-1}$ ), and hypothesis tests on particular fixed effects, denoted by the $D$ statistic (Eqn 5) d.f., Degrees of freedom; null hypothesis rejected at $\dagger P<0.1, * P<0.5, * * P<0.01$

\begin{tabular}{|c|c|c|c|}
\hline \multirow[t]{2}{*}{ Parameter } & \multicolumn{3}{|c|}{$\log \left(C_{\mathrm{s}}\right)$} \\
\hline & $0-0.1 \mathrm{~m}$ & \multicolumn{2}{|c|}{$0-0.3 \mathrm{~m}$} \\
\hline$\overline{\text { (Intercept) }}$ & $-1.76 \times 10^{-2}$ & \multicolumn{2}{|c|}{$-1.42 \times 10^{-3}$} \\
\hline sumTSDM & $8.27 \times 10^{-6}$ & \multicolumn{2}{|c|}{$5.91 \times 10^{-6}$} \\
\hline $\operatorname{sigTSDM}$ & $7.38 \times 10^{-9}$ & \multicolumn{2}{|c|}{$1.59 \times 10^{-9}$} \\
\hline FM300slope & $-2.22 \times 10^{-2}$ & \multicolumn{2}{|c|}{$-0.76 \times 10^{-2}$} \\
\hline sRate & $-3.24 \times 10^{-3}$ & \multicolumn{2}{|c|}{$-4.14 \times 10^{-3}$} \\
\hline soilOrder_Chromosol & $-4.54 \times 10^{-2}$ & \multicolumn{2}{|c|}{$-3.76 \times 10^{-2}$} \\
\hline soilOrder_Dermosol & $1.39 \times 10^{-2}$ & \multicolumn{2}{|c|}{$4.29 \times 10^{-2}$} \\
\hline soilOrder_Hydrosol & $5.84 \times 10^{-1}$ & \multicolumn{2}{|c|}{$6.86 \times 10^{-1}$} \\
\hline soilOrder_Kandosol & $-0.51 \times 10^{-1}$ & \multicolumn{2}{|c|}{$-1.24 \times 10^{-1}$} \\
\hline soilOrder_Sodosol & $1.38 \times 10^{-1}$ & \multicolumn{2}{|c|}{$1.45 \times 10^{-1}$} \\
\hline soilOrder_Tenosol ${ }^{\mathrm{A}}$ & $0.72 \times 10^{-1}$ & \multicolumn{2}{|c|}{$1.46 \times 10^{-1}$} \\
\hline domGrass_Exotic buffel & $-6.89 \times 10^{-2}$ & \multicolumn{2}{|c|}{$-2.33 \times 10^{-2}$} \\
\hline domGrass_Exotic other & $-3.75 \times 10^{-1}$ & \multicolumn{2}{|c|}{$-3.26 \times 10^{-1}$} \\
\hline grazMan_Cell & $1.27 \times 10^{-2}$ & \multicolumn{2}{|c|}{$-6.27 \times 10^{-2}$} \\
\hline grazMan_Rotational & $1.88 \times 10^{-2}$ & \multicolumn{2}{|c|}{$-3.91 \times 10^{-2}$} \\
\hline grazMan_Exclosure & $1.24 \times 10^{-2}$ & \multicolumn{2}{|c|}{$0.37 \times 10^{-2}$} \\
\hline \multirow[t]{2}{*}{ Null hypothesis } & \multirow[t]{2}{*}{ d.f. } & \multicolumn{2}{|c|}{$D$} \\
\hline & & $0-0.1 \mathrm{~m}$ & $0-0.3 \mathrm{~m}$ \\
\hline sumTSDM $=0$ & 1 & $13.76 * *$ & $10.57 * *$ \\
\hline $\operatorname{sig} T S D M=0$ & 1 & 0.18 & 0.01 \\
\hline FM300slope $=0$ & 1 & 2.27 & 0.46 \\
\hline sRate $=0$ & 1 & 2.09 & $3.49 \dagger$ \\
\hline soilOrder $=0$ & 6 & $14.23 *$ & $25.64 * *$ \\
\hline domGrass $=0$ & 2 & $11.85^{* *}$ & $13.30^{* *}$ \\
\hline$($ grazMan_Continous - grazMan_Cell $)=0$ & 1 & 0.06 & $2.77 \dagger$ \\
\hline$($ grazMan_Continous - grazMan_Rotational $)=0$ & 1 & 0.12 & 0.84 \\
\hline$($ grazMan_Continous - grazMan_Exclosure $)=0$ & 1 & 0.06 & 0.01 \\
\hline$($ grazMan_Cell - grazMan_Rotational $)=0$ & 1 & 0.01 & 0.34 \\
\hline$($ grazMan_Cell - grazMan_Exclosure $)=0$ & 1 & $<0.01$ & $2.86 \dagger$ \\
\hline (grazMan_Rotational - grazMan_Exclosure $)=0$ & 1 & 0.01 & 1.08 \\
\hline
\end{tabular}

${ }^{\mathrm{A}} \mathrm{A}$ single occurrence of Rudosol in the data was re-allocated to Tenosol, a taxonomically close match, for this analysis.

associated with strongly above-average values of $\varepsilon_{\mathrm{GAM}}$. Again, this was an expected result, because wet soil tends to accumulate (or lose more slowly) SOC. The dominant grass category domGrass 'Exotic other' (defined as $>25 \%$ of the site comprising exotic grass species Bothriochloa pertusa and Urochloa sp.) was associated with strongly below-average values of $\varepsilon_{\mathrm{GAM}}$. Grazing management, in the form either sRate or grazMan, had no effect on $\varepsilon_{\mathrm{GAM}}$ at $0-0.1 \mathrm{~m}$ depth. At $0-0.3 \mathrm{~m}$ depth, however, sRate had a small but significant negative effect on $\varepsilon_{\mathrm{GAM}}$. There was also a significant difference in $\varepsilon_{\mathrm{GAM}}$ between Continuous and Cell grazing (where Continuous $>$ Cell), and between Cell and Exclosure (where Exclosure $>$ Cell) at $0-0.3 \mathrm{~m}$.

\section{Discussion}

Average SOC stocks reported in this study are similar to those reported for Australian tropical and subtropical grazing systems (Sanjari et al. 2008; Pringle et al. 2011; Witt et al. 2011) and within the range reported for other grazing lands in Australia and elsewhere (Derner and Schuman 2007; Chan et al. 2010;
Silver et al. 2010). The dominant influences on SOC stocks vary according to the spatial scale at which the inventory is undertaken, although general trends have been identified in the literature. At a regional to global scale, climatic information related to moisture or water availability (incorporating approximated first-order variables such as precipitation, evapotranspiration, and temperature) appear strongly related to SOC, with second-order edaphic factors, such as soil drainage/water retention, highlighting indirectly the effect of soil texture on SOC at local scales (Wynn et al. 2006; Bui et al. 2009). This is supported in our study, which identified temperature and vapour pressure deficit (strongly related to evapotranspiration) as the dominant regional factors (explaining $>80 \%$ of the variation in SOC to $0.3 \mathrm{~m}$ soil depth), and Hydrosol soil as a strong influence on SOC stocks at a local scale. In other studies of grazing land, potential evapotranspiration and precipitation (growing season, mean annual) have also been identified as important factors controlling SOC (Bai et al. 2012; Shi et al. 2012).

Various regional-scale studies have assessed the impact of grazing on SOC stocks along environmental gradients, although 
these effects are often inconsistent and difficult to predict (Derner and Schuman 2007; Piñeiro et al. 2010). Since identification of grazing management relies on detailed information regarding stocking density and grazing duration (often hard to directly obtain), pasture management variables (e.g. control of vegetation ground coverage and pasture utilisation rate) are also used to assess grazing intensity (Manley et al. 1995; Han et al. 2008; Sanjari et al. 2008; Stahlheber and D'Antonio 2013). In the current study, the significant reduction in SOC stocks with decreasing pasture TSDM, and the small but significant decrease in SOC with increasing 'stocking rate' (Table 3) appear to support the general trend of decreased SOC at higher grazing intensities reported by others. The effect of grazing intensity and duration (Cell and Rotational strategies) was less clear; we found that Cell grazing had slightly but significantly reduced SOC stocks compared with Exclosure or Continuous grazing (possibly reflecting grazing intensity), although the overlap of grazing management strategies and limited information on stocking density (measured as stock days per ha or total stock days) restricted a definitive assessment. Other studies report no significant differences in SOC when comparing timecontrolled and rotationally grazed plots with continuous grazing (Sanjari et al. 2008; Chan et al. 2010). Chan et al. (2010) attributed lack of significant differences in SOC stocks between Continuous and Rotational management practices to several factors, including: inherent problems associated with site history information (management history and length of study); the survey approach, including large field-scale variability; and the small magnitude of treatment effects reported.

A range of mechanistic processes - including primary productivity and species composition, root:shoot allocation of nutrients, and changes to decomposition and carbon export through landscape processes - have been associated with the influence of grazing activity on carbon cycling (Piñeiro et al. 2009; Stahlheber and D'Antonio 2013). These mechanistic drivers are likely to respond at local and broader spatial scales, and it has been proposed that the influence of grazing occurs across a precipitation 'threshold', where carbon cycling is constrained by water availability in semi-arid regions, and by nutrient availability, particularly nitrogen, in subhumid and humid regions (Derner and Schuman 2007; Piñeiro et al. 2009). While our interpretation is constrained by the limited level of pasture information available in this study, it is possible that some of these mechanistic effects are captured in our grazing management variable domGrass (Table 1), with domGrass Exotic Other (consisting of $>25 \%$ Bothriochloa pertusa and Urochloa sp.), associated with significantly smaller SOC stocks than the domGrass Exotic Buffel (>25\% Cenchrus ciliaris) and domGrass Native Grass ( $>25 \%$ native pasture species) categories (Table 3). Possible explanations for these smaller SOC stocks include: (i) change in SOC input through decreased aboveground and root biomass inputs, e.g. a shift from deeper rooting tufted species to weakly tufted roots spreading at nodes; (ii) short- and/or long-term changes in microbial turnover and decomposition of soil organic matter or 'priming effects' (Blagodatskaya and Kuzyakov 2008; Zhang et al. 2013); or (iii) that the result reflects previous change in SOC stocks due to previous land-use history and climate (e.g. poor land condition, erosion, and drought).

Interpretation of management effects on SOC stocks identified in this study should be treated with caution, since SOC stocks were determined by one-off sampling of sites and were not directly repeated-measurement of sites over time. Identification of the effects of grazing management in this study was restricted by the statistical power of the composite samples, and was also constrained by the spatial support of covariate data used in the GAM. Since there is a lack of baseline data to enable direct comparison of change over time, we consider the spatial variability of SOC stocks using the GAM to identify trends in management consistent throughout the landscape, and assume that a minimum of 10 years is an adequate period to enable detection of significant changes in SOC stocks in response to grazing management. Dean et al. (2012a) note that substituting space-for-time can be inferior to long-term experimental sites, since the former approach needs to take into account spatial heterogeneity, appropriate site-pairing, and interconnections for SOC in time.

We also acknowledge that SOC stocks and grazing management may interact with longer range climate, e.g. extended drought, and it is possible that realisation of detectable differences may occur over longer periods than the time-frame identified in this study. Inclusion of a measure of climatic variability, in addition to the climatic averages used within this study, might influence the GAM, e.g. inclusion of rainfall variability and its relationship with 'effective' rainfall may have associated impacts on plant growth (and organic matter input). The GAM implemented in this study assumes uncorrelated model residuals, and this subsequently confers an (unquantified) bias on the LMM. Implementation of a GAM in a 'mixed' form, as a way to minimise bias, has been proposed (see Kammann and Wand 2003) and is a topic for future research; alternatively, the scale issues we have encountered suggest a role for Bayesian hierarchical models (Gelman et al. 2004).

The explanatory power of environmental and grazingmanagement factors in relation to SOC stocks in the northeastern Australian rangelands may be strengthened in the following ways:

(1) Through incorporation of quantitative information to support classification of the grazing-management continuum. In some regions, nominal Rotational and Cell grazing strategies overlap, with Continuous grazing loosely adopted and/or integrated with wet-season spelling (e.g. Chan et al. 2010). In practice, the Cell grazing strategy is a more intensive form of the Rotational strategy, whereas some Continuous systems incorporate extensive rest periods. Grazing management information relating to stocking density (stocking rate, total graze days, stock days per ha, reported as agreed standard units) may be more informative for SOC stocks, whereas nominal grazing management classes (used to stratify land use) risk masking potential trends.

(2) Long-term replicated trials, with sampling occurring across at least two periods, would assist assessment of change of SOC stocks; further, exploration of the humus and particulate SOC composition of these samples may 
provide insights about SOC turnover periods and incorporation into more stable SOC pools (Han et al. 2008; Wynn and Bird 2008; Klumpp et al. 2009).

(3) In the absence of measured nitrogen data, a sensitivity analysis could be undertaken to indicate whether nitrogen could have changed the outcome reported in this study and to assist in defining future research needs.

(4) Through geo-referenced archiving of individual soil samples, for comparison of management treatments at the property level, and to support continued study of spatial and temporal variability of SOC. Access to archived soils is beneficial for accounting and prediction of SOC change, including development of scenario models assessing the interactions between climate, land management, and soil carbon, e.g. component models within FullCAM, used to construct Australia's national greenhouse gas emissions account for the land sector (Richards and Evans 2000; Hill et al. 2006; Biggs and Grundy 2010; Sanderman and Baldock 2010).

(5) Remote sensing offers a promising way to improve the spatial representation of SOC stocks (Pringle 2013). Further, remote sensing derived information on belowground biomass would assist biophysical, process-based and carbon-accounting models such as AussieGRASS (Carter et al. 2000) and FullCAM (Richards and Evans 2000).

\section{Conclusion}

From a large pool of explanatory variables (related to grazing management, climate, soil, and topography), SOC stocks in the north-eastern Australian grazing lands were strongly (and nonlinearly) affected by temperature and vapour pressure deficit. Following detrending for the climate effects, we found a strong influence of total standing dry matter, soil type, and the dominant grass species on SOC stocks. The influence of grazing management was less easy to determine; a small negative influence of stocking rate on SOC stocks was detected, while SOC stocks were slightly lower in Cell grazing than in other nominal grazing strategies (Rotation, Continuous, and Exclosure). This may be due to several reasons: the small number of samples due to compositing; the 'fuzziness' of the grazing management classes; and the limited information available on grazing frequency and intensity (e.g. in the form of stock days per ha or total graze days). Further work is required to describe the relationship between management parameters and SOC stocks with confidence across the north-eastern Australian grazing lands. A key challenge will be to ensure background response(s) to climate variability and inherent soil properties are taken into account.

\section{Acknowledgements}

We thank the Department of Agriculture, Fisheries and Forestry as well as Meat and Livestock Australia for providing funding for this project. We thank Jim Payne and Angie Woods for soil sampling assistance and Lynette Appleton, Justin McCoombes, Bernadette Jones, and Kerrilyn Catton for soil processing. Finally, we are grateful to participating land managers for site access.

\section{References}

Australian Government Department of Sustainability, Environment, Water, Population and Communities (2013) Australian Rangeland Boundaries Digital Map. Available at: www.environment.gov.au/metadataexplorer/ full_metadata.jsp?docId=\%7B65CDB640-5977-4BDF-AF24-07A9312 9B808\%7D\&loggedIn=false.

Bai Y, Wu J, Clark CM, Pan Q, Zhang L, Chen S, Wang Q, Han X (2012) Grazing alters ecosystem functioning and C:N:P stoichiometry of grasslands along a regional precipitation gradient. Journal of Applied Ecology 49, 1204-1215. doi:10.1111/j.1365-2664.2012.02205.x

Baldock JA, Sanderman J, Macdonald L, Puccini A, Hawke B, Szarvas S, McGowan J (2013) Quantifying the allocation of soil organic carbon to biologically significant fractions. Soil Research 51, 561-576.

Bastin G ACRIS Management Committee(2008) 'Rangelands 2008Taking the pulse. Australian Collaborative Rangelands Information System.' (National Land and Water Resources Audit, Commonwealth of Australia: Canberra, ACT)

Biggs AJW, Grundy MJ (2010) The need for better links between pedology and soil carbon research in Australia. Australian Journal of Soil Research 48, 1-6. doi:10.1071/SR09064

Bishop TFA, McBratney AB, Laslett GM (1999) Modelling soil attribute depth functions with equal-area quadratic smoothing splines. Geoderma 91, 27-45. doi:10.1016/S0016-7061(99)00003-8

Blagodatskaya E, Kuzyakov Y (2008) Mechanisms of real and apparent priming effects and their dependence on soil microbial biomass and community structure: critical review. Biology and Fertility of Soils $\mathbf{4 5}$, 115-131. doi:10.1007/s00374-008-0334-y

Breiman L (2001) Random forests. Machine Learning 45, 5-32. doi:10.1023/A:1010933404324

Bui E, Henderson B, Viergever K (2009) Using knowledge discovery with data mining from the Australian Soil Resource Information System database to inform soil carbon mapping in Australia. Global Biogeochemical Cycles 23, GB4033. doi:10.1029/2009GB003506

Carter JO, Hall WB, Brook KD, McKeon GM, Day KA, Paull CJ (2000) Aussie GRASS: Australian Grassland and Rangeland Assessment by Spatial Simulation. In 'Applications of seasonal climate forecasting in agricultural and natural ecosystems - the Australian experience'. (Eds G Hammer, N Nicholls, C Mitchell) pp. 329-349. (Kluwer Academic Press: Dordrecht)

Chan KY, Oates A, Li GD, Conyers MK, Prangnell RJ, Poile G, Liu DL, Marchia IM (2010) Soil carbon stocks under different pastures and pasture management in the higher rainfall areas of south-eastern Australia. Australian Journal of Soil Research 48, 7-15. doi:10.1071/ SR09092

Cohen J (1960) A coefficient of agreement for nominal scales. Educational and Psychological Measurement 20, 37-46. doi:10.1177/00131644 6002000104

Cook GD, Williams RJ, Stokes CJ, Hutley LB, Ash AJ, Richards AE (2010) Managing sources and sinks of greenhouse gases in Australia's rangelands and tropical savannas. Rangeland Ecology and Management 63, 137-146. doi:10.2111/08-101.1

de Gruijter JJ, Brus DJ, Bierkens MFP, Knotters M (2006) 'Sampling for natural resource monitoring.' (Springer: Berlin)

Dean C, Roxburgh SH, Harper RJ, Eldridge DJ, Watson IW, WardellJohnson GW (2012a) Accounting for space and time in soil carbon dynamics in timbered rangelands. Ecological Engineering 38, 51-64. doi:10.1016/j.ecoleng.2011.10.008

Dean C, Wardell-Johnson GW, Harper R (2012b) Carbon management of commercial rangelands in Australia: Major pools and fluxes. Agriculture, Ecosystems \& Environment 148, 44-64. doi:10.1016/j.agee.2011.11.011

Department of Environment and Resource Management (2011) 'Managing grazing lands in Queensland.' (Department of Environment and Resource Management, Queensland: Brisbane, Qld) 
Derner JD, Schuman GE (2007) Carbon sequestration and rangelands: A synthesis of land management and precipitation effects. Journal of Soil and Water Conservation 62, 77-85.

Gelman A, Carlin JB, Stern HS, Rubin DB (2004) 'Bayesian data analysis.' 2nd edn (Chapman \& Hall/CRC: Boca Raton, FL)

Gifford RM, Roderick ML (2003) Soil carbon stocks and bulk density: spatial or cumulative mass coordinates as a basis of expression? Global Change Biology 9, 1507-1514. doi:10.1046/j.1365-2486.2003. 00677.x

Hall TJ, McIvor J, Jones P, MacLeod N, McDonald C, Reid D, Smith D, Delaney K (2011) 'Investigating intensive grazing systems in northern Australia. Vol. I.' Final Project Report B.NBP.0353. (Meat and Livestock Australia Limited: North Sydney, NSW)

Han G, Hao X, Zhao M, Wang M, Ellert BH, Williams W, Wang M (2008) Effect of grazing intensity on carbon and nitrogen in soil and vegetation in a meadow steppe in Inner Mongolia. Agriculture, Ecosystems \& Environment 125, 21-32. doi:10.1016/j.agee.2007. 11.009

Hastie TJ, Tibshirani RJ (1990). 'Generalised additive models.' (Chapman and Hall: New York)

Hill MJ, Roxburgh SH, McKeon GM, Carter JO, Barrett DJ (2006) Analysis of soil carbon outcomes from interaction between climate and grazing pressure in Australian rangelands using Range-ASSESS. Environmental Modelling \& Software 21, 779-801. doi:10.1016/j. envsoft.2005.02.006

Isbell RF (2002) 'The Australian Soil Classification.' (CSIRO Publishing: Melbourne)

Jeffrey SJ, Carter JO, Moodie KM, Beswick AR (2001) Using spatial interpolation to construct a comprehensive archive of Australian climate data. Environmental Modelling \& Software 16, 309-330. doi:10.1016/S1364-8152(01)00008-1

Kammann EE, Wand MP (2003) Geoadditive models. Journal of the Royal Statistical Society. Series A, (Statistics in Society) 52, 1-18.

Klumpp K, Fontaine S, Attard E, Le Roux X, Gleixner G, Soussana JF (2009) Grazing triggers soil carbon loss by altering plant roots and their control on soil microbial community. Journal of Ecology 97, 876-885. doi:10.1111/j.1365-2745.2009.01549.x

Lark RM, Cullis BR (2004) Model-based analysis using REML for inference from systematically sampled data on soil. European Journal of Soil Science 55, 799-813. doi:10.1111/j.1365-2389.2004.00637.x

Linn DM, Doran JW (1984) Effect of water-filled pore space on carbon dioxide and nitrous oxide production in tilled and nontilled soils. Soil Science Society of America Journal 48, 1267-1272. doi:10.2136/ sssaj1984.03615995004800060013x

Liu DL, Chan KY, Conyers MK, Li G, Poile GJ (2011) Simulation of soil organic carbon dynamics under different pasture managements using the RothC carbon model. Geoderma 165, 69-77. doi:10.1016/j.geoderma. 2011.07.005

Malone BP, McBratney AB, Minasny B, Laslett GM (2009) Mapping continuous depth functions of soil carbon storage and available water capacity. Geoderma 154, 138-152. doi:10.1016/j.geoderma.2009. 10.007

Manley JT, Schuman GE, Reeder JD, Hart RH (1995) Rangeland soil carbon and nitrogen responses to grazing. Journal of Soil and Water Conservation 50, 294-298.

McBratney AB, Minasny B (2010) Comment on "Determining soil carbon stock changes: Simple bulk density corrections fail" [Agric. Ecosyst. Environ. 134 (2009) 251-256. Agriculture, Ecosystems \& Environment 136, 185-186. doi:10.1016/j.agee.2009.12.010

Piñeiro G, Paruelo JM, Jobbágy EG, Jackson RB, Oesterheld M (2009) Grazing effects on belowground $\mathrm{C}$ and $\mathrm{N}$ stocks along a network of cattle exclosures in temperate and subtropical grasslands of South America. Global Biogeochemical Cycles 23, GB2003. doi:10.1029/ 2007GB003168
Piñeiro G, Paruelo JM, Oesterheld M, Jobbágy EG (2010) Pathways of grazing effects on soil organic carbon and nitrogen. Rangeland Ecology and Management 63, 109-119. doi:10.2111/08-255.1

Pringle MJ (2013) Robust prediction of time-integrated NDVI. International Journal of Remote Sensing 34, 4791-4811. doi:10.1080/01431161. 2013.782117

Pringle MJ, Allen DE, Dalal RC, Payne JE, Mayer DG, O'Reagain PO, Marchant BP (2011) Soil carbon stock in the tropical rangelands of Australia: Effects of soil type and grazing pressure, and determination of sampling requirement. Geoderma 167-168, 261-273. doi:10.1016/j. geoderma.2011.09.001

R Core Team (2013) R: A language and environment for statistical computing. $\mathrm{R}$ Foundation for Statistical Computing, Vienna. Available at: www.R-project.or

Rayment GE, Higginson FR (1992) 'Australian laboratory handbook of soil and water chemical methods.' (International Books Australia P/L, Inkata Press: Melbourne)

Richards GP, Evans DMW (2000) 'Full Carbon Accounting Model (FullCAM).' (National Carbon Accounting System, Australian Greenhouse Office: Canberra, ACT)

Rickert KG, Stuth JW, McKeon GM (2000) Modelling pasture and animal production. In 'Field and laboratory methods for grassland and animal production research'. (Eds L 't Mannetje, RM Jones) pp. 29-66. (CABI Publishing: New York)

Sammon JW (1969) A non-linear mapping for data structure analysis. IEEE Transactions on Computers C-18, 401-409. doi:10.1109/T-C.1969. 222678

Sanderman J, Baldock JA (2010) Accounting for soil carbon sequestration in national inventories: a soil scientist's perspective. Environmental Research Letters 5, 034003. doi:10.1088/1748-9326/5/3/034003

Sanjari G, Ghadiri H, Ciesiolka CAA, Yu B (2008) Comparing the effects of continuous and time-controlled grazing systems on soil characteristics in Southeast Queensland. Australian Journal of Soil Research 46, 348-358. doi:10.1071/SR07220

Shi Y, Baumann F, Ma Y, Song C, Kühn P, Scholten T, He JS (2012) Organic and inorganic carbon in the topsoil of the Mongolian and Tibetan grasslands: pattern, control and implications. Biogeosciences 9, 2287-2299. doi:10.5194/bg-9-2287-2012

Silver WL, Ryals R, Eviner V (2010) Soil carbon pools in California's annual grassland ecosystems. Rangeland Ecology and Management 63, 128-136. doi:10.2111/REM-D-09-00106.1

Speight JG (2008) Landform. In 'Australian soil and land survey field handbook'. 3rd edn (The National Committee on Soil and Terrain, Australian Collaborative Land Evaluation Program: Canberra, ACT)

Stahlheber KA, D'Antonio CM (2013) Using livestock to manage plant composition: A meta-analysis of grazing in California Mediterranean grasslands. Biological Conservation 157, 300-308. doi:10.1016/j. biocon.2012.09.008

Viscarra Rossel RA, Webster R (2011) Discrimination of Australian soil horizons and classes from their visible-near infrared spectra. European Journal of Soil Science 62, 637-647. doi:10.1111/j.1365-2389.2011. 01356.x

Webster R, Oliver MA (2001) 'Geostatistics for environmental scientists.' (John Wiley \& Sons: Chichester, UK)

Welham SJ, Thompson R (1997) Likelihood ratio tests for fixed model terms using residual maximum likelihood. Journal of the Royal Statistical Society. Series B. Statistical Methodology 59, 701-714. doi:10.1111/ 1467-9868.00092

Witt GB, Noël MV, Bird MI, Beeton RJS, Menzies NW (2011) Carbon sequestration and biodiversity restoration potential of semi-arid mulga lands of Australia interpreted from long-term grazing exclosures. Agriculture, Ecosystems \& Environment 141, 108-118. doi:10.1016/j. agee.2011.02.020 
Wood SN (2008) Fast stable direct fitting and smoothness selection for Generalized Additive Models. Journal of the Royal Statistical Society. Series B. Methodological 70, 495-518. doi:10.1111/j.1467-9868.2007. 00646.x

Wynn JG, Bird MI (2008) Environmental controls on the stable carbon isotopic composition of soil organic carbon: implications for modelling the distribution of $\mathrm{C}_{3}$ and $\mathrm{C}_{4}$ plants, Australia. Tellus 60B, 604-621.

Wynn JG, Bird MI, Vellen L, Grand-Clement E, Carter J, Berry SL (2006) Continential-scale measurement of the soil organic carbon pool with climatic, edaphic, and biotic controls. Global Biogeochemical Cycles $\mathbf{2 0}$, GB1007. doi:10.1029/2005GB002576

Yule DF (1984) Volumetric calculations in cracking clay soils. In 'Properties and utilization of cracking clay soils'. (Eds J McGarity, E Hoult, HB So) pp. 136-140. (University of New England: Armidale, NSW)

Zhang W, Wang X, Wang S (2013) Addition of external organic carbon and native soil organic carbon decomposition: A meta-analysis. PLOS ONE 8, e54779. doi:10.1371/journal.pone.0054779 